\title{
Bioactive Components of Three Seaweed Species from Hadji Panglima Tahil, Sulu Philippines
}

\author{
Maribelle Hanani \\ Department of Aquaculture, Mindanao State University, Sulu, Philippines
}

Email address:

mabelle2003@yahoo.com

To cite this article:

Maribelle Hanani. Bioactive Components of Three Seaweed Species from Hadji Panglima Tahil, Sulu Philippines. Agriculture, Forestry and Fisheries. Vol. 10, No. 4, 2021, pp. 127-131. doi: 10.11648/j.aff.20211004.12

Received: May 12, 2021; Accepted: June 26, 2021; Published: July 13, 2021

\begin{abstract}
This study aimed to determine the bioactive composition and properties of three selected marine seaweeds: Ulva reticulata, Halymenia durvillei and Sargassum cristaefolium from Hadji Panglima Tahil, Sulu Philippines. The proximate and heavy metal composition of the seaweeds were determined. Heavy metal analysis in seaweeds showed that zinc registered highest concentration $(328.74 \mathrm{mg} / \mathrm{kg})$ in U. reticulata. Other evaluated seaweed species registered lower concentrations of copper $(\mathrm{Cu})$, mercury, and lead indicating that they could be eaten as source of $\mathrm{Cu}$. The concentration reveals that these seaweeds could be source of the micronutrient, and copper. All other seaweeds are safe for human consumption. Nutritional proximate composition of seaweeds in this study revealed that the brown seaweed (i.e. S. cristaefolium) collected from Hadji Panglima Tahil, Sulu Philippines had highest average composition in terms of moisture, lipids, and total soluble solids. Results on nutritional proximate composition of seaweed varies due to the effect of geographical location, time of collection and the weather condition. Dried samples of $U$. reticulata showed best antioxidant activity while $S$. cristaefolium had least antioxidant activity. Sulu Philippines is one of the seaweeds suppliers in western Mindanao. Decades ago, seaweeds are known as food delicacy like Caulerpa, Eucheuma and Gracilaria spp. They are eaten raw while the industrial and medicinal uses of extracts from seaweeds were known later by inhabitants. There have been several feeding trials conducted to have the potential as source of aqua feed. Feeding the fishes with seaweed helps to prevent the occurrence of disease to certain extent. Seaweeds contain plenty of protein, vitamin and minerals. Moreover, seaweeds also contain potential bioactive compounds which exhibit antibacterial, antiviral and antifungal properties. The phytochemicals responsible for the bioactivities could be present in the seaweeds which based on literature. In addition to "positive" roles, seaweeds also play critical roles in reef degradation, particularly in ecological "phase shifts" where abundant reef-building corals are replaced by abundant fleshy seaweed. Indeed, the seaweeds screened in this study possess bioactive components and antioxidant which may be considered for future applications in medicine, cosmetics, and some heavy metals composition which may be considered for future applications in food industry.
\end{abstract}

Keywords: Seaweed, Bioactive Components, Feeds, Nutrition, Phytochemical, Heavy Metals

\section{Introduction}

Seaweeds are the only sources of phytochemicals namely: agar-agar, carrageenan and algin. They are also used as feedstuff for animal consumption [2]. Seaweeds contain different varies of inorganic and organic substances which can be used for human health for example: polyphenols, carotenoids and tocopherols, terpenes, ascorbic acid and alkaloid [5]. Due to high amounts of vitamins and minerals present in green seaweeds, they are used widely in agriculture, pharmaceutical, biomedical and nutraceutical industries [7].
In the Philippines, utilization of Sargassum by coastal populations include; 1 . As cover for fishery products to prevent desiccation and maintain their freshness; 2. As food; 3. As fertilizer, insect repellant, flower inducer and animal feed; and 4. As therapeutic drink, among others. Sargassum biomass is also believed to have a great potential as feedstuff for alternative sources of energy, i.e. biofuel [11].

Sulu is one of the seaweeds suppliers in western Mindanao. Decades ago, seaweeds are known as food delicacy like 
Caulerpa, Eucheuma and Gracilaria spp. Seaweed industry is considered as one of the major industries that benefits the majority of coastal fisher-folks. Eucheuma and Kappaphycus spp. are the potential seaweeds used for culture and farm in Sulu. Seaweeds like Sargassum, Ulva and Halymenia spp. are just flaking in the shoreline for no one knows their benefits. Other places like in Ilocos Norte, It is their favorite take home or "pasalubong" when they return back to their residences abroad [1].

Ecologically, the seaweed commodity provides a number of benefits to the surrounding environment against various environmental unfriendly catching activities, like, use of poisons and bombs in catching fish. Biologically, seaweed plays an important role as primary producer of organic materials and oxygen at the coastal environment. Economically, this is potential commodity to be developed, considering its nutrient content and pharmaceutical uses. It can be used as foodstuffs such as agar, vegetables, and snacks. It also produces algin materials, carrageenan and fluseran used in pharmaceutical, cosmetic, and textile industries, and as an alternative feeds to fish. Seaweeds also contain potential bioactive compounds which exhibit antibacterial, antiviral and antifungal properties [10].

This study was conducted to analyze the proximate heavy metal composition and phytochemical components of seaweeds viz, Ulva reticulata, Sargassum cristaefolium and Halymenia durvillei, collected from Hadji Panglima Tahil, Sulu, Philippines.

Objective of the Study

The study generally aimed to determine the bioactive composition and properties of three selected marine species.

Specifically, it determined:

1. Proximate and heavy metal composition of selected marine seaweeds,

2. Phytochemical components of the $U$. reticulata, $S$. cristaefolium and $H$. durvillei.

\section{Materials and Methods}

\subsection{Collection of Samples}

Seaweed samples of Ulva reticulata, Sargassum cristaefolium and Halymenia durvillei were hand-picked from Hadji Panglima Tahil, Sulu. Seaweeds identification was based on their morphological characteristics. Immediately after collection, samples were cleaned and washed with seawater to remove extraneous matter such as epiphytes, sand particles, pebbles and shells and they were put in an iced container to maintain low temperate during transportation.

Samples were sorted and thoroughly cleaned with distilled water and dried under shady, open-air condition for one week and then oven dried for one hour at $50^{\circ} \mathrm{C}$. Dried samples were ground in a miley mill and packed in zip-locked container and brought to the laboratory for chemical proximate analysis. Remaining powdered samples were then stored in $-20^{\circ} \mathrm{C}$ freezer for further analysis. All analyses of the seaweed samples were carried out in triplicates.

Seaweed is vast fishery resources found everywhere and anywhere on bodies of water around the world. Sulu Philippine are known site and for their abundance of seaweeds species. Sulu is known for culturing the seaweeds Eucheuma, Gracilaria and Kappaphycus spp. and these seaweed species are part of their livelihood and diets of the Suluanos. The rest of seaweeds are just waste natural product that can be seen floating and flaking along the shoreline. While in other places like in Ilocos Norte, seaweeds are also part of Ilocano diets and as well as a source of their livelihood but seaweeds are not cultured or farmed in the area.

\subsection{Proximate Composition Analysis}

Semi- dried seaweeds samples were submitted to the Regional Science and Technology Laboratory, Department of Science and Technology for proximate composition analysis. Nutrient composition of raw seaweeds was analyzed by Association of Official Analytical Chemists (AOAC) method. Percentage moisture, protein, lipid and ash were determined. The crude protein of the seaweeds was determined using the Micro-Kjeldahl method [13]. Estimation of fat content of experimental seaweeds was done using the Bligh and Dryer method [3]. Pulverized seaweed samples (3 g) were weighed and ignited in the crucible. Then they were transferred in the Muffle Furnace and heated at $550-600^{\circ} \mathrm{C}$ for $6-8$ hours until the residue was white. Finally, percentage of moisture, protein, fat and ash content were calculated according to the following formula:

Calculation of moisture:

$$
\text { Moisture (\%) }=\frac{\text { Weight loss }}{\text { Original weight of sample taken }} \times 100
$$

Calculation of protein:

$\mathrm{N}_{2}(\%)=$ (Titration reading-blank reading) $x$ strength of acid $x 100 / 5 \times 100 /$ weight of the sample. Percentage of protein in the sample was calculated by multiplying $\%$ of $\mathrm{N}_{2}$ with an empirical factor 6.25: Protein $(\%)=\%$ of total $\mathrm{N}_{2} \times 6.2$

Calculation of fat:

$$
\text { Fat }(\%)=\frac{\text { Weight of the residues }}{\text { Weight of the residues }} \times 100
$$

Calculation of ash:

$$
\text { Ash }(\%)=\frac{\text { Weight of dry samples }}{\text { Weight of the samples taken }} \times 100
$$

\subsection{Determination of Chemical Composition of Seaweeds}

Seaweed samples were brought and submitted to Region III Department of Science and Technology Feed Testing Center in Pampanga for heavy chemical analysis. Heavy metals like mercury, lead, zinc and copper content of the raw seaweeds were analyzed by their Association of Official Analytical Chemists (AOAC) methods of analysis with the application of different methods shown in Table 1. 
Table 1. Methods used in the analysis of carbohydrates, sodium and total soluble sugar.

\begin{tabular}{ll}
\hline Parameter & TEST Method \\
\hline \multirow{3}{*}{ Carbohydrates } & By Computation \\
& $\%$ Carbohydrates $=100 \%-(\%$ Ash $+\%$ Moisture $+\%$ Fat $+\%$ Protein $)$ \\
& TM-230 \\
& AOAC Methods of Analysis $18^{\text {th }}$ ed. \\
Sodium & Official Method 956.01 (Modified $)$ \\
& Flame Photometric Method \\
& TM-206 \\
Total Soluble Sugar & AOAC Methods of Analysis $18^{\text {th }}$ ed. \\
\hline
\end{tabular}

Table 2. Test on nutritional components of seaweed.

\begin{tabular}{ll}
\hline PARAMETER & TEST METHOD \\
\hline \multirow{2}{*}{ Ash Content } & TM-201 \\
& AOAC Methods of Analysis $18^{\text {th }}$ ed.. Official Method 925.51A, Furnace Ashing $525^{\circ} \mathrm{C}, 12 \mathrm{hr}$ \\
& TM-202 \\
Crude Fat & Velp Fat Hydrolysing Unit \& Fat Extractor Manuals \\
& Using Petroleum ether \\
& TM-203 \\
Moisture Content & AOAC Methods of Analysis $18^{\text {th }}$ ed. Official Method $930.04 \& 930.15$, Oven Drying $130^{\circ} \mathrm{C}, 2 \mathrm{hr}$ \\
& TM- 204 \\
Crude Protein & AOAC Methods of Analysis $18^{\text {th }}$ ed. and Velp Scientica Distillation Apparatus Operation Manual, Factor for $\%$ Nitrogen content \\
& conversion to protein $=6.25$ \\
\hline
\end{tabular}

Table 3. Methods used in chemical analysis for seaweeds.

\begin{tabular}{ll}
\hline PARAMETER & TEST METHOD \\
\hline \multirow{2}{*}{ Mercury } & AOAC Methods of Analysis 18 $8^{\text {th }}$ ed. \\
& Official Method 972.25 (Modified) Flameless Atomic Absorption Spectrophotometric Method, Thermal Decomposition \& \\
& Amalgamation of DMA-80 Manual \\
Lead, Zinc and Copper & $\begin{array}{l}\text { AOAC Methods of Analysis } 18^{\text {th }} \text { ed. } \\
\text { Official Method 999.11 Atomic Absorption Spectrophotometric Method \& Varian AAS Manual }\end{array}$ \\
\hline
\end{tabular}

\section{Results and Discussion}

\subsection{Heavy Metals Uptakes of Seaweed}

The aim was to measure concentrations of total copper $(\mathrm{Cu})$, lead $(\mathrm{Pb})$, mercury $(\mathrm{Hg})$ and zinc $(\mathrm{Zn})$ in three edible seaweed species from Hadji Panglima Tahil, Sulu Philippines. Heavy metal concentrations in three seaweeds of the metal analyzed, $\mathrm{Zn}$ registered highest concentration $(328.74 \mathrm{mg} / \mathrm{kg}$ ) in $U$. reticulata growing in the area. Other seaweeds registered lower concentration and other could be eaten as source of copper.

Lead and $\mathrm{Hg}$ are toxic heavy metals and they were also detected in seaweeds. Ulva seaweeds collected from the area were found to contain seemingly high level of $\mathrm{Pb}$.

However, no maximum contaminant level values that were specifically set for $\mathrm{Pb}$ or $\mathrm{Hg}$ in seaweeds were found, so there was no guideline or standard value that could serve as reference to determine whether measured concentration is higher or lower than maximum allowable intake value.

In addition, results revealed in this study that levels of the heavy metals or trace elements in seaweeds in Sulu vary according to composition of seaweed uptakes of $\mathrm{Hg}, \mathrm{Pb}, \mathrm{Zn}$ and $\mathrm{Cu}$. This could be due to effect of location, type of sediments, and salinity of seawater and weather condition during time of sampling.

\subsection{Proximate Composition of the Seaweeds as Feeds}

Ulva reticulata has high protein (17.91\%) and ash content (37.38\%). Halymenia durvillei is high in moisture content $(11.07 \%)$ while $S$. cristaefolium is high in fiber $(8.59 \%)$ and ash content (15.07\%) on dry basis. Based on the FAO report (2009), protein contents of the green and red seaweeds are quite variable. Protein contents of the green seaweeds ranged from 6.00 to $26.00 \%$ while red ranged from 3.00 to $29.00 \%$. This study found protein content of green and red seaweeds to be between these ranges.

Fresh $U$. reticulata from Tanzania was analyzed to have $25.70 \%$ crude protein, $18.30 \%$ ash and $38.50 \%$ crude fiber [12]. Oven dried meal red seaweeds from Philippines, Kappaphycus alvarezii and Gracilaria heteroclada, contain 3.2 and $17.3 \%$ crude protein, respectively [14].

Environmental condition in Hadji Panglima Tahil Sulu is conducive to growth of $H$. durvillei and $U$. reticulata in terms of better proximate composition. In case of $S$. cristaefolium, indicates that environmental condition can produce better proximate composition of this species of seaweeds. It has been established that seaweed meal increases fertility and birthrate of animals and improves color to salmonids [6].

There have been several feeding trials conducted to evaluate seaweeds as fish feed. They have been used as fresh and dried 
meal incorporated as partial or complete replacement of fishmeal protein in pelleted form. Dietary inclusion levels in these studies ranged from 5-100\% [8]. Addition of Porphyras pheroplasts to semi-purified diet of red sea bream (Marantes corymbosa) improved their specific growth rate [9]. When dried, Gracilaria busrapastonis replaced 5 or $10 \%$ of fish protein hydrolysate diet for European sea bass (Dicentrarchus labrax) specific growth rate improved [15].

Thus, seaweeds evaluated in present study also have the potential as source of aqua feed. Feeding the fishes with seaweed helps to prevent the occurrence of disease to certain extent. Seaweeds contain plenty of protein, vitamin and minerals. Most studies were on tilapia and submerged macrophytes were fed either in fresh form or as dried meal within pelleted diet. In addition, $4 \%$ of Sargassum meal to the feed of shrimp cultures reduced cholesterol contents of their muscle tissue by $29 \%$ quite desirable for shrimp grown for human consumption [4].

\section{Summary and Conclusion}

This study aimed to determine the bioactive components and properties of three selected marine seaweeds viz Ulva reticulata, Halymenia durvillei and Sargassum cristaefolium from Hadji Panglima Tahil, Sulu. The proximate and heavy metal compositions of the seaweeds were determined. Qualitative phytochemical screenings was applied.

Aside from determining proximate composition, this study also evaluated the heavy metal concentrations in seaweeds. Among the metals analyzed, zinc registered highest concentration $(328.74 \mathrm{mg} / \mathrm{kg})$ in U. reticulata growing in the area. Other evaluated seaweed species registered lower concentrations of copper $(\mathrm{Cu})$, mercury $(\mathrm{Hg})$, and lead $(\mathrm{Pb})$.

The concentration reveals that these seaweeds could be source of the micronutrient, copper. In addition, except for $U$. reticulata, all other seaweeds are safe for human consumption and could be used as raw material for other purposes such as drug or cosmetics preparation

Lead and $\mathrm{Hg}$ are toxic heavy metals and they were also detected in the seaweeds. Ulva reticulata collected sample were found to contain seemingly high level of $\mathrm{Pb}$.

However, no maximum contaminant level values that were specifically set for $\mathrm{Pb}$ or $\mathrm{Hg}$ in seaweeds were found, so there was no guideline or standard value that could serve as reference to determine whether the measured concentration is higher or lower than maximum allowable value.

Seaweed appears to be interesting source for medicinal and phytochemical studies. Presence of phytochemicals in three seaweeds observed in this study confirmed the presence of terpenoids in both ethanol and methanol extracts. Terpenoids are important as additive in the food industry and as a pharmaceutical agent in biomedicine. Tannins, saponins and coumarins were present in $U$. reticulata while alkaloids, flavonoids and xantho-proteins were absent in both methods.

This difference can be attributed to solubility of the active component in different solvents and methods of extraction were possible source of variation for the chemical composition and bio-activity of the extracts..

In conclusion, the seaweeds screened in this study possess bioactive and some heavy metals composition which may be considered for future applications in food industry. In the next research studies, further investigation should be undertaken to characterize the other compounds residing in these types of seaweed as well as to evaluate the effects of each individual compound in fish and microorganism.

\section{Recommendations}

For heavy metals, conduct watershed assessment and evaluation that should include minimum identification pollutant source and identification of the critical area.

Enhancement of information dissemination to local farmers, for sustainable aquaculture, as seaweeds are known for their bioactive components in nutritional and pharmaceutical uses.

Encourage and support production of these seaweeds in terms of formulation of alternative or supplemental feeding on tilapia for sustainable aquaculture purposes.

Enhancement information on cosmetology, for seaweeds have therapeutically benefits for skin diseases like acne and melisma.

\section{Acknowledgements}

This work would not have been possible without the financial support of Department of Science and Technology-PCMARD and PCAARRD, the help of certain individuals in Central Luzon State University and to her alma mater, Mindanao State University-Sulu her utmost gratitude for the completion of this research study.

\section{References}

[1] AGNGARAYNGAY, Z. M. 2000. Edible Seaweeds of Ilocos Norte: Food Preparations other Local Uses and Market Potentials..

[2] ANANTHARAMAN P., K. MANIVANNAN, G. KARTHIKAIDEVI and G. THIRUMARAN. 2009. Element composition of certain seaweeds from Gulf of Mannar Marine Biosphere Reserve, Southeast Coast of India. World Journal of Dairy and Food Sciences 4 (1): 46-55.

[3] BLIGH, E. G., and W. J. DYER. 1959. A rapid method of total lipid extraction and purification. Canadian Journal of Biochemistry and Physiology 37: 913-917.

[4] CASAS-VALDEZ, M., H. HERNANDEZ- CONTRERAS, A. MARIN-ALVAREZ, R. AGUILA-RAMIREZ, C. J. HERNANDEZ-GUERRERO, L. SANCHEZ- RODRIGUEZ, and S. CARILLO- DOMINGUEZ. 2006. The seaweed Sargassum (Sargassaceae) as tropical alternative for goats' feeding. Revista de Biologia Tropical 54 (1): 83-92.

[5] CHANDA S., R. DAVE, M. KANERIA, and K. NAGANI. 2010. Seaweeds: a novel, untapped source of drugs from sea to combat infectious diseases. In: A. Mendez-Vilas (Ed). Current Research, Technology and Education Topics in Applied Microbial Biotechnology. pp. 473-480. 
[6] CHAPMAN, V. J. AND CHAPMAN, D. J. 1980. Seaweed and Their Uses. Chapman \& Hall, London.

[7] COX, S., N. GHANNAM, and S. GUPTA. 2010. An assessment of the antioxidant and antimicrobial activity of six species of edible Irish seaweeds. International Food Research Journal 17: 205-220.

[8] FAO 2009. The state of world fisheries and aquaculture, 2008. FAO Fisheries and 531 Aquaculture Department. Food and Agriculture Organization of the United Nations, 532 Rome.

[9] KALLA, A., T. YOSHIMATSU, T. ARAKI, D. ZHANG, T. YAMAMOTO, and S. SAKAMOTO. 2008. Use of Porphyra spheroplasts as feed additive for red sea bream. Fisheries Science 74: 104-108.

[10] MARINHO-SORIANO E., P. C. FONSECA. M. A. A. CARNEIRO, W. S. C. MOREIRA WSC. 2006. Seasonal variation in the chemical composition of two tropical seaweeds. Bio-resources Technology 97: 2402-2406.
[11] MONTANO, M. N., M. C. RODRIQUEZA, and R. L. BALITAAN. 2006. Ethnobotany of Sargassum spp. in the Philippines. Coastal Marine Science Journal 30 (1): 222-225.

[12] MSUYA, F. E. and A. NEORI. 2002. Ulva reticulata and Gracilaria crassa: macroalgae that can bio-filter effluent from tidal fishponds in Tanzania. Western Indian Ocean Journal of Marine Science 1: 117-216.

[13] PEARSON, D. 1999. Pearson's Composition and Analysis of Foods. University of Reading.

[14] PENAFLORIDA, V. D. and N. V. GOLEZ. 1996. Use of seaweed meals from Kappaphycus alvarezii and Gracilaria heteroclada as binders in diets for juvenile shrimp Penaeus monodon. Aquaculture 143 (3-4): 393-401.

[15] VALENTE, L. M. P., A. GOUVENIA, P. REMA, J. MALTOS, E. F. GOMES, and I. S. PINTO. 2006. Evaluation of three seaweeds Gracilaria bursa-pastoris, Ulva rigida and Gracilaria cornea as dietary ingredients in European sea bass (Dicentrarchus labrax) juveniles. Aquaculture 252: 85-91. 